\title{
Parents Perception about Thalassemia among Bangladeshi Thalassemic Children
}

\author{
Dr. Mohammad Shawkat Hossain Khan ${ }^{1 *}$, Dr. Md. Shafiqul Islam², Dr. Md. Asaduzzaman ${ }^{3}$, Dr. Md. Noor Uddin
} Talukder ${ }^{4}$, Dr. Habiba Jesmin ${ }^{5}$, Dr. Fakhrul Amin Badal ${ }^{6}$

\footnotetext{
1,2,4,5 Assistant Professor, Department of Pediatrics, Sheikh Hasina Medical College, Tangail, Bangladesh

${ }^{3}$ Assistant Professor, Department of Pediatrics, Sheikh Sahera Khatun Medical College, Gopalganj, Bangladesh

${ }^{6}$ Residential Physician (RP), Pediatrics, 250 Bedded General Hospital, Tangail, Bangladesh
}

DOI: $10.36347 /$ sjams.2020.v08i06.039

| Received: 12.06.2020 | Accepted: 20.06.2020 | Published: 30.06.2020

*Corresponding author: Dr. Mohammad Shawkat Hossain Khan

\section{Abstract}

Original Research Article

Objective: In this study our main aim is to evaluate the level of awareness about thalassemia among the parents of thalassemic children. Method: This was a Hospital based cross sectional observational study which was conducted at Department of Pediatrics, SaheedZiaur Rahman Medical College Hospital, Bogura, Bangladesh from November 2010 to November 2011 where total 50 parents of thalassemia children were selected by simple randomization. Results: During the study, most of the parents $72 \%$ thought thalassemia as a curable disease and only $08 \%$ of the parents had idea about the genetic basis of the disease. According to types of thalassemia $28 \%$ patients had Beta thalassemia major and $72 \%$ had E-beta thalassemia. Perceptions about the prevention of thalassemia among parents were very poor. $100 \%$ of them noticed thalassemia as a non-preventable disease and all of them had no idea about the prevention of the disease. Conclusion: Awareness about the disease among the parents is poor and the availability of antenatal diagnosis is not available readily. Bone marrow transplantation is out of reach for most of the parents because of financial constraints. Therefore, conservative treatment remains the choice in developing countries like Bangladesh. Parental awareness regarding various aspects of thalassaemia is of great importance not only for the prevention of thalassaemia in the family, but also for the proper management of thethalassaemic children.

Keywords: Thalassaemia, blood transfusion and iron chelation.

Copyright @ 2020: This is an open-access article distributed under the terms of the Creative Commons Attribution license which permits unrestricted use, distribution, and reproduction in any medium for non-commercial use (NonCommercial, or CC-BY-NC) provided the original author and source are credited.

\section{INTRODUCTION}

Thalassaemia is a wide spread and heterogeneous group of inherited disorder characterized by the reduction or absence of globin chains. There is defect in the synthesis of globin chains. In the ancient time it was known as Mediterranean Anemia as it was particularly prevalent among Mediterranean peoples and this geographical association was responsible for its naming. Thalassa is Greek for the sea and Haeme is Greek for blood thus it means the sea in the blood. It was first recognized by a Detroit pediatrician Thomas Cooley in 1925.In 1932 George H Whipple and William L Brandford published a comprehensive account of the pathologic finding in this disease. The true genetic nature of this disorder was fully appreciated after 1940[12]. Now it is clear that the disease described by Cooley, later on by Whipple, is the homozygous state of an autosomal muted gene, for which the heterogygous state is associated with much milder hematologic change.
Thalassaemia is the most common congenital disorder in the world including Bangladesh. $\mathrm{Hb} \mathrm{E}$ carriers are healthy and beta thalassaemia carriers are also normal except that some of them mildly anaemic. The carrier status of beta thalassaemia trait in our population is $4.1 \%$ and of $\mathrm{Hb} \mathrm{E}$ trait is $6.1 \%$. The expected births of beta thalassaemia major infants annually are about 1040 and $\mathrm{Hb} \mathrm{E}$ beta thalasaemia are about 6443[9]. This number is insignificant in contrast to the number of patients of other diseases like diarrhea, acute respiratory infections etc. But those diseases are not life time diseases. Here children get sick, get treatment, are cured and few may die [3]. The infant mortality of infectious diseases has drastically fallen due to targeted programs of vaccination, better nutrition and better health care facilities. Treatment of thalassaemia is different from acute illnesses in that emphasis on maintaining health rather than getting better and getting out [4]. When thalassaemia is diagnosed in a child, s/he becomes a patient for his/her life time and therefore one patient becomes 12 as these patients have to come to a hospital or a thalassemia 
center for blood transfusion or for other complications every month.

With global improvement in childhood diseases, due to prevention and treatment with targeted programs to prevent mortality from malnutrition, diarrhea $\&$ acute respiratory infections, thalassemia will become a major issue in Bangladesh in this millennium [3]. World Health Organization (WHO) estimates that at least $6.5 \%$ of the world populations are carries of different inherited disorders of Hemoglobin. It is predicted that when the world population finally stabilizes, at least $8.0 \%$ of the world population will be the carrier or trait of different types of Thalassemia syndromes \& hemoglobinopathies[5]. The world population of carriers of beta thalassemia trait is reported to be more than 100 million worldwide and about 100,000 children with thalassemia major are born each year [5].

In this study our main aim is to evaluate the parent's perception about thalassemia among the Bangladeshi thalassemic children.

\section{OBJECTIVE}

\section{General objective}

- To assess the level of awareness about thalassemia among the parents of Bangladeshi thalassemic children.

\section{Specific objective}

- To identify types of thalassemia in the children.

- To detect parents' perceptions about prevention for thalassemia.

\section{METHODOLOGY}

Types of the study

- This study was a Hospital based cross sectional observational study having both descriptive and analytic components

\section{Place and period of the Study}

- This study was conducted at Department of Pediatrics, SaheedZiaur Rahman Medical College Hospital, Bogura from November 2010 to November 2011 where total 50 parents of thalassemic children were selected by simple randomization.

\section{Inclusion Criteria}

- Parents of those children who were previously diagnosed as THALASSEMIA and confirmed by $\mathrm{Hb}$ - Electrophoresis, done outside as the investigation facility was not available at the study place. One parent could be conducted only once.

\section{Data Processing and Analysis}

- The collected answer of the questions was analyzed and expressed in percentage of participant parents giving answers of the questions. The data and results were presented in the form of tables and diagram where applicable.

\section{RESULTS}

Table-1 showed the general knowledge about thalassemia among the parents most of the parents $72 \%$ thought thalassemia as a curable disease and only $08 \%$ of the parents had idea about the genetic basis of the disease. The following table is given below in detail:

Table-1: General Knowledge about Thalassemia

\begin{tabular}{|c|c|c|}
\hline Characters & No & $\%$ \\
\hline 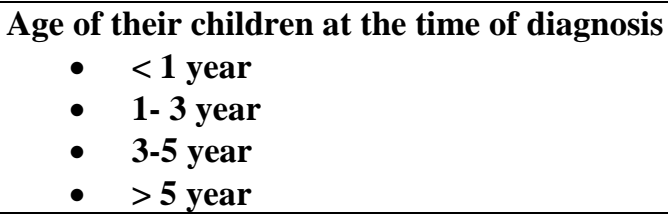 & $\begin{array}{l}00 \\
28 \\
12 \\
10\end{array}$ & $\begin{array}{l}00 \% \\
56 \% \\
24 \% \\
20 \%\end{array}$ \\
\hline $\begin{array}{c}\text { Is the disease curable } \\
\qquad \quad \text { Yes } \\
-\quad \text { No }\end{array}$ & $\begin{array}{l}36 \\
14 \\
\end{array}$ & $\begin{array}{l}72 \% \\
28 \% \\
\end{array}$ \\
\hline $\begin{array}{l}\text { What sort of disease thalassemia is? } \\
\text { - Infectious } \\
\text { - Contagious } \\
\text { - Genetic } \\
\text { - Don't know }\end{array}$ & $\begin{array}{l}06 \\
12 \\
04 \\
28\end{array}$ & $\begin{array}{l}12 \% \\
24 \% \\
08 \% \\
56 \%\end{array}$ \\
\hline
\end{tabular}

In figure-1 shows distribution of the patients according to types of thalassemia where $28 \%$ patients had Beta thalassemia major and $72 \%$ had E beta thalassemia. The following figure is given below in detail: 


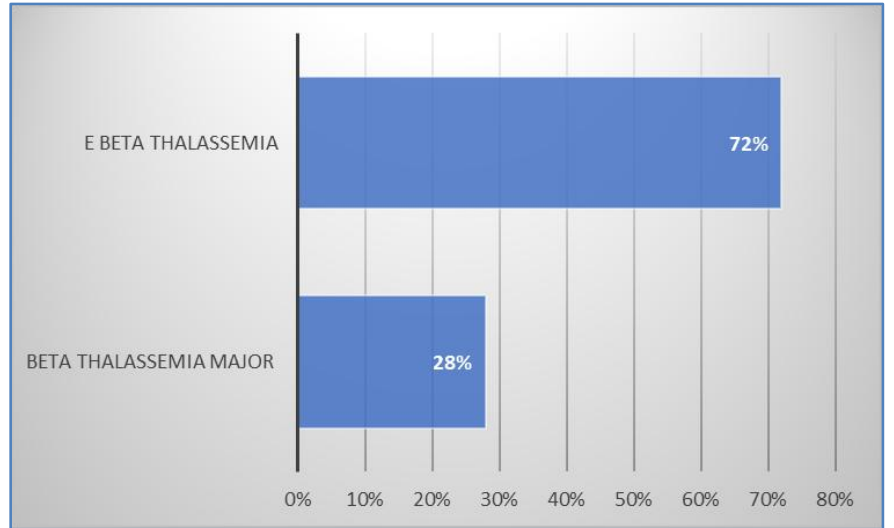

Fig-1: Distribution of the patients according to types of thalassemia

In table-2 shows perceptions about the prevention of thalassemia among parents were very poor. $100 \%$ of them noticed thalassemia as a non- preventable disease and all of them had no idea about the prevention of the disease. The following table is given below in detail:

Table-2: Perceptions about prevention

\begin{tabular}{|c|c|l|}
\hline Items & \multicolumn{1}{c|}{ No } & \multicolumn{1}{c|}{} \\
\hline Is it preventable? & & \\
$\bullet \quad$ Yes & 00 & $00 \%$ \\
$\bullet \quad$ No & 50 & $100 \%$ \\
\hline & & \\
How can be prevented & & \\
$\bullet \quad$ Marriage counseling & 00 & $00 \%$ \\
$\bullet \quad$ Carrier detection & 00 & $00 \%$ \\
$\bullet \quad$ Don't know & 50 & $100 \%$ \\
\hline
\end{tabular}

In table- 3 shows parent's perceptions about the treatment of thalassemia. $80 \%$ parents had no idea about chelating therapy. Also, no children got their hepatitis B vaccine. The following table is given below in detail:

Table-3: Perceptions about treatment of Thalassemia

\begin{tabular}{|c|c|c|c|}
\hline \multicolumn{2}{|l|}{ Items } & No & $\%$ \\
\hline \multirow[b]{3}{*}{ Food and drug habits } & $\begin{array}{l}\text { Do you Know the name of foods to avoid } \\
\text { - Yes } \\
\text { - } \quad \text { No } \\
\end{array}$ & $\begin{array}{l}22 \\
28 \\
\end{array}$ & $\begin{array}{l}44 \% \\
56 \% \\
\end{array}$ \\
\hline & $\begin{array}{l}\text { Do you Know the name of drugs to avoid } \\
\qquad \quad \text { Yes } \\
\qquad \quad \text { No } \\
\end{array}$ & $\begin{array}{l}18 \\
32 \\
\end{array}$ & $\begin{array}{l}36 \% \\
64 \% \\
\end{array}$ \\
\hline & $\begin{array}{l}\text { Do you Know the bad effect of oral iron therapy? } \\
\text { - Accumulates in body } \\
\text { - Harmful to the child } \\
\text { - Don't know } \\
\end{array}$ & $\begin{array}{l}00 \\
10 \\
40\end{array}$ & $\begin{array}{l}00 \% \\
20 \% \\
80 \% \\
\end{array}$ \\
\hline \multirow{4}{*}{ Blood transfusion } & $\begin{array}{c}\text { Source of blood to be transfused } \\
-\quad \text { Blood bank } \\
-\quad \text { Others } \\
\end{array}$ & $\begin{array}{l}36 \\
14 \\
\end{array}$ & $\begin{array}{l}72 \% \\
28 \% \\
\end{array}$ \\
\hline & $\begin{array}{c}\text { Why screening test done before transfusion } \\
\text { - For Hepatitis } \\
\text { - } \quad \text { For HIV } \\
\text { - } \quad \text { For diarrhea } \\
\text { - } \quad \text { Don't know } \\
\end{array}$ & $\begin{array}{l}00 \\
00 \\
04 \\
46\end{array}$ & $\begin{array}{l}00 \% \\
00 \% \\
08 \% \\
92 \%\end{array}$ \\
\hline & $\begin{array}{c}\text { Effect of repeated transfusion in thalassemia } \\
\text { - Iron over load } \\
\text { - Disease transmission } \\
\text { - Don't know } \\
\end{array}$ & $\begin{array}{l}00 \\
00 \\
50\end{array}$ & $\begin{array}{l}00 \% \\
00 \% \\
100 \%\end{array}$ \\
\hline & $\begin{array}{l}\text { Has your child been vaccinated for hepatitis B } \\
\qquad \quad \text { Yes } \\
\bullet \quad \text { No } \\
\end{array}$ & $\begin{array}{l}00 \\
50 \\
\end{array}$ & $\begin{array}{l}00 \% \\
100 \% \\
\end{array}$ \\
\hline
\end{tabular}


In figure-2 shows distribution of the patients according to chelating therapy where most didn'treceived any chelating therapy $88 \%$. The following figure is given below in detail:

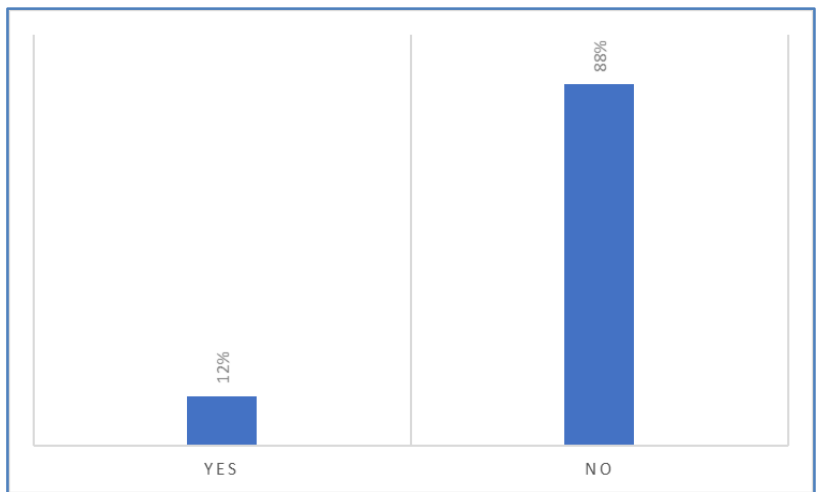

Fig-2: Distribution of the patients according to chelating therapy

In figure-3 shows distribution of the patient according to splenectomy where only $4 \%$ had splenectomy and $96 \%$ didn't have any splenectomy. The following figure is given below in detail:

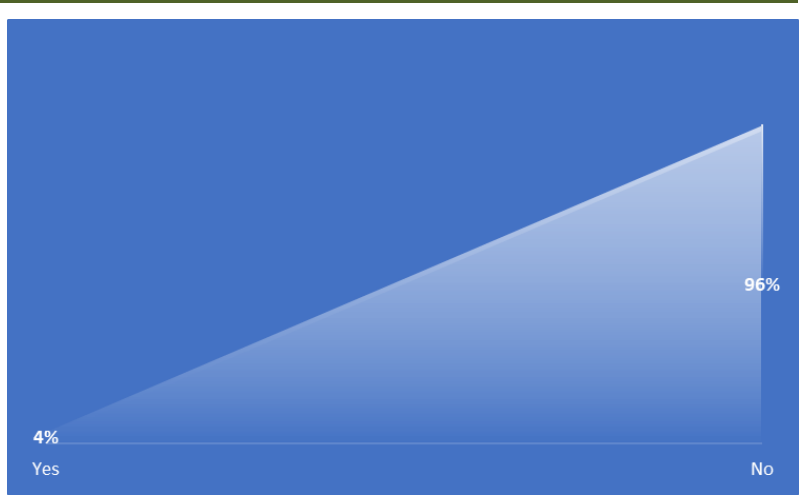

Fig-3: Distribution of the patient according to splenectomy

Knowledge about blood transfusion was also poor. Perceptions about foods $44 \%$ and drugs $36 \%$ to avoid were better and only $04 \%$ of the thalassemia children had done splenectomy.

This table- 3 shows relation between Education level of parents and their children getting Chelating Therapy where a very low number of children $12 \%$ were receiving chelating therapy. The following table is given below in detail:

Table-3: Relation between Education level of parents and their children getting Chelating Therapy

\begin{tabular}{|l|l|l|l|}
\hline $\begin{array}{l}\text { Education level of } \\
\text { the parents }\end{array}$ & $\begin{array}{l}\text { No of } \\
\text { parents }\end{array}$ & $\begin{array}{l}\text { No of the children getting Chelating therapy } \\
\text { among different Education level }\end{array}$ & $\begin{array}{l}\text { \% of children getting } \\
\text { Chillating therapy }\end{array}$ \\
\hline Illiterate & 18 & 00 & $00 \%$ \\
\hline Literate & 28 & 02 & $7.14 \%$ \\
\hline Educated & 04 & 04 & $100 \%$ \\
\hline Highly educated & 00 & 00 & $00 \%$ \\
\hline
\end{tabular}

\section{DisCUSSION}

$24 \%$ parents had history of consanguineous marriage and $92 \%$ of the parents had no idea about the genetic basis of the disease. Regardless of consanguinity and non-consanguinity most of the children were suffering from $\mathrm{Hb}$ E-Beta Thalassemia $72 \%$. All the parents had no idea about the prevention and type of the disease. These knowledge deficits may result in unnecessary anxiety among the parents and may have profound emotional effects on the family. Public health message should focus on the type of the disease and the disease only manifests severely in individuals who are homozygous.

Regarding the perceptions about the treatment of thalassemia only $44 \%$ and $36 \%$ of the parents knew the food and drugs to avoid respectively, $92 \%$ of them had no idea about the screening of blood before transfusion, $100 \%$ of them had no knowledge regarding the bad effect of repeated blood transfusion, $12 \%$ of the children were receiving chelating therapy but all these children on chelating therapy were from educated parents. This situation refracts a general lack of knowledge among the parents of Bangladeshi thalassemic children.
In this present study parents noticed that age at which thalassemia diagnosed was $56 \%$ within $1-3$ years; indicate early diagnosis of the disease. Another study from Pakistan showed that thalassemia was diagnosed in $65 \%$ of the children within 08 months after birth [6].

In this present study parent's perceptions about a national screening program and medical termination of pregnancy was not evaluated but these things were considered in other studies. ${ }^{7-8}$ Some of those are considered here which could help later on to establish a new study work.

A study from Iran showed most of the recent advances in medical genetics has been in basic science and technology. Experience of translating these into effective, population-based interventions is limited, but the potential is great, especially for lower resource countries. This is well illustrated by the experience of the national thalassaemia screening program in Iran, a comprehensive, primary care-based program for screening and genetic counseling. Since the program's inception in 1996 premarital screening of 2.7 million couples has been carried out over five years, followed by genetic counseling of more than 10000 couples who were found to be positive. This has resulted in a $70 \%$ 
reduction in the expected annual birth rate of affected infants. ${ }^{9}$ For a vast, lower resource country with a population of 68 million, this is a considerable achievement

\section{Conclusion}

Awareness about the disease among the parents is poor and the availability of antenatal diagnosis is not available readily. Bone marrow transplantation is out of reach for most of the parents because of financial constraints. Therefore, conservative treatment remains the choice in developing countries like Bangladesh.Parental awareness regarding various aspects of thalassaemia is of great importance not only for the prevention of thalassaemia in the family, but also for the proper management of thalassaemic children.

\section{ReFERENCE}

1. Weather all. William's Haematology: The Thalassemias, page 518-615, 5th edition, New York, Mc Graw Hill; 1995.
2. Khan WA. December, Battle against Thalassaemia, the Daily Star; 2008.

3. Public perception and attitude toward thalassemia: Influencing factors in a muli racial population; $\mathrm{Li}$ Ping Wong, Elizabeth George, Jin Ai Mary Tan; BMC Public Health. 2001; 11:193

4. Rahman MJ, Rahman MH, September, Pretension \& control strategy of thalassaemia in Bangladesh, The ORION. 2003; 16

5. WHO. WHO guidelines for control of hemoglobin disorders. Unpublished document; 1994. WHO/HDP/HB/Gl/94., Geneva, Switzerland, Obtainable free of charge from the Hereditary Disease Program, WHO.

6. FehminaArif, Jabeen Fayyaz, Ahmed Hamid. Awareness among parents of children with thalassaemia major, JPMA. 2008; 58: 621.

7. Khan MR and Rahman ME. Essence of Pediatrics, chapter15, 3rd ed, Dhaka, Anwara Khan; 2004.

8. Khan WA. June -December, Thalassemia in Bangladesh, DS (Children) H journal.1999; 15(1,2): 42-44.

9. Arnold Christianson, Allison Streetly, AamraDarr; Lessons From Thalassemia Screening in Iran; BMJ. 2004; 329: 1115-7. 